\title{
Network Positioning and Risk Perception in Servitization: Evidence from the UK Road Transport Industry
}

\author{
Ali Ziaee Bigdeli ${ }^{a *}$, Oscar F. Bustinza ${ }^{b}$, Ferran Vendrell-Herrero ${ }^{c}$, and Tim Baines ${ }^{\text {a }}$ \\ ${ }^{a}$ Aston Business School, Aston University, Birmingham, B4 7ET, UK. \\ ${ }^{b}$ Department of Management, University of Granada, Granada, Spain \\ ${ }^{c}$ Birmingham Business School, University of Birmingham, United Kingdom
}

\begin{abstract}
For manufacturing firms, the integration of advanced services into their customer offerings has become a crucial decision. Such commercial decisions require weighting the risks and rewards of implementing a business model based on advanced services. While academic experts acknowledge uncertainty of returns on investment despite potential advantages, research generally fails to address the challenge of calculating the actual risks involved in 'servitization'. This paper seeks better understanding of managers' risk perception and of servitization implications for strategic partnerships and network positioning, while considering the impact of factors such as entry barriers, technological knowledge and position in the supply chain (SC). Qualitative evidence is drawn from an industrial case study involving firms in the UK's road transport industry: fourteen in-depth interviews with senior executives from seven companies (manufacturers, operators, technology providers). During interviews, a payment card exercise measured risk perception and willingness to take strategic 'make-or-buy' decisions. Results suggest that implementing advanced services is perceived as a high-risk strategy, especially when firms lack in-house technological knowledge. However, collaborative strategic partnerships within supply chain networks can mitigate this risk and prove crucial to building entry barriers against external competitors. Based on these findings, implications for network positioning are developed.
\end{abstract}

Keywords: Servitization, risk perception, network positioning, strategic partnership, advanced services. 


\section{Introduction}

The question of "how can services add value" has increasingly attracted manufacturing firms. This highlights that competitive position and expanded operations cannot be safeguarded simply through technical improvements to physical products (Visnjic et al., 2017). A growing number of manufacturers have begun to base their competitive strategies on service provision, or 'servitization' (Vandermerwe and Rada, 1989; Kowalkowski et al., 2017). Essentially, manufacturers that 'servitize' set out to grow revenue streams and profits by offering services rather than just products (Baines and Lightfoot, 2013; Crozet and Milet, 2017).

Although broadening focus from products to services is fundamental to the servitization debate, 'services' are not homogeneous but differ substantially - in risk level, competition level, and potential to create competitive advantage (Huikkola et al., 2016; Zhang et al., 2016; Mahut et al., 2017). Following on logically from this, there are various forms of servitization. Some manufacturers create wealth by offering a wide range of 'break-fix' services in which the outcome focuses on the product provision (usually categorised as 'intermediate services'); others develop fewer, more sophisticated, high-value contracts, usually termed 'advanced services' "services whose outcome focuses on capability delivered through product performance" (Baines and Lightfood, 2013, p.66), such as Rolls-Royce's TotalCare and Xerox's 'pay-per-click' document scanning, copying and printing. Industrial services are thus categorised according to the nature of the value proposition the supplier provides, that is, on input-based promise promise to perform a deed, and output-based or advanced services - to achieve enhanced performance (Ulaga and Reinartz, 2011).

Advanced services are central to the servitization debate. They change the relationship between customer, provider and network partners significantly, and require the providing businesses to adopt new technologies and organisational structure (Ardolino et al., 2017; Rabetino et al., 2017). Those new technologies are reshaping the nature of firm's strategies and business models, ultimately affecting competition (Porter and Heppelmann, 2014). Servitization thus directly affects the whole set of the firm's network relationships. In managing this effect on network partner relationships, many firms implementing advanced services engage in strategic partnerships to gain competitive advantage (Lockett et al., 2011). According to Ellram and Cooper (1990), potential benefits are economic (transferring financial risks), managerial (effective outsourcing of decision-making), and strategic (better SC positioning). However, adopting and implementing advanced services is perceived as a high-risk strategy (Durugbo, 2014) due to uncertainties regarding potential loss of strategic focus, resource constraints and internal conflicts (Josephson et al., 2016). Because network partner relationships and technology 
deployment strategies are key to successful/sustainable transition to service provision, this paper provides a cohesive analysis, and yet comprehensive understanding of both the impact of the network relationships on the journey to servitization and network positioning, and the risk associated with technology implementation in servitizing contexts.

Previous papers on servitization and SCs examine development of firm strategy within a supply chain network -SCN- (Chang et al., 2012), firms' structural power derived from position in this network (Bastl et al., 2013), and ways of securing network power from the advanced services provider's perspective (Finne et al., 2015). Such work highlights the need for further analysis of assumptions underlying service-led growth achieved by manufacturers from a knowledge-based perspective (Valtakoski, 2016) and for clarification of how servitizing firms handle knowledge accumulation and willingness to share strategic information with network partners.

Building on prior research, we aim to answer "can manufacturing firms maintain network dominance when implementing advanced services locked upstream in the value chain?". Therefore, three objectives were defined for this research; first, we examine risk perception surrounding introduction and implementation of advanced services. Utilising empirical data from the UK road transport industry, this paper employs a payment card method (Epstein and Widener, 2011) to examine and estimate expected premiums associated with such risks. Specifically, this method measures the expected financial premium point to determine willingness to implement advanced services. This analysis makes an incremental contribution to research, as few studies have produced a quantitative measure of the risks underlying advanced service implementation (Bikfalvi et al., 2013; Benedettini et al., 2015).

Second, we examine the extent to which firms implementing advanced services position themselves in the network by employing strategic partnerships. Another contribution of this research is thus to analyse risk-related motivations underlying the development of strategic partnerships in the context of servitization. This issue is important because servitization involves organisational changes to accommodate involvement with customers (Bustinza et al., 2013) and intermediaries (Vendrell-Herrero et al., 2017), and developing partnerships with other firms in the network may reduce the risks associated with those changes (Bustinza et al., 2017; Rabetino et al., 2017).

Third, we consider visibility of the entire value chain. Visibility is achieved by representing the value chain so that alternative supply chain solutions can be identified, based on an analysis of provider position and customer demand (Collin et al., 2009). Including visibility is an additional input of this research, since introducing services supported by, or related to, 
product use is a strategic move downstream that manufacturing firms make to secure additional revenue (Wise and Baumgartner, 1999) and a sustainable source of competitive advantage (Baines and Lightfoot 2013). We fill a research gap by providing better understanding of how such strategies should be adopted and implemented within the supply chain network, with consideration of the visibility of the entire value chain, as a prerequisite to implementing advanced services (Holmstron et al., 2010).

Following this introduction, we review existing literature on strategic partnerships, network dominance, and risk perception associated with adoption and delivery of advanced services; describe our research methodology and analyse data collected from the UK road transport industry and discuss key findings. The conclusion presents implications for research and practice, study limitations and suggestions for future research.

\section{Theoretical background}

\section{Strategic partnership and value network positioning}

Firms' implementation and delivery of advanced services are influenced by their position in the SCN (Bustinza et al., 2015). Firms realise that partnerships with key players in the value network constitute a strategic move that can result in capturing more value (Xie et al., 2014), a decision that has been studied in different contexts, including partnership to provide productservice offerings (Lockett et al., 2011). To understand how strategic partnerships affect network positioning in the context of implementing advanced services, we first examine the dynamics of supply chain management (SCM), explained below, and of the SCN, considered as the network of firms involved in the different processes for the entire production of goods and services (Lambert and Cooper, 2000).

For Cooper et al. (1997), SCM encompasses process integration throughout organisations and the SC. Firms become interconnected, and one firm's successful implementation of processes and functions may affect success of the entire SC (Skjøtt-Larsen et al., 2007). Linkage facilitates conceiving of SCNs as tiers of suppliers and customers (Lambert et al., 1996). Whereas 'traditional' manufacturers use traditional product-oriented SCNs, servitized manufacturers manage complex service networks including supplier-customer relationships that are both product-oriented and vertically integrated (Gebauer et al., 2013; Brax and Visintin, 2017).

SCNs encompass both network firms and their interconnection, and identify key SC members with whom processes must be linked (Lambert and Cooper, 2000). A firm's 
environment includes a network structure with a dyadic level (single supplier-buyer relationships) and a network level (upstream-to-downstream) (Ritter and Gemünden, 2003). SCNs are also the context for resource configurations enabling development and delivery of successful services (Raddats et al., 2015). Analysing the SCN becomes crucial to better understanding of point of entry into the network. Managers must determine appropriate levels of partnership for specific SC links (Lambert et al., 1996) to ensure strong network positioning.

Past research discusses how the most powerful partners secure greater shares of network profits (see for instance Gelderman et al., 2008; Meehan and Wright, 2012). In this context, firms gain power by controlling access to key resources, thereby influencing operational and strategic decisions of other value chain members (Finne et al., 2015). Moreover, these strategic decisions are closely related to the firms' accumulated knowledge (information asymmetry), valuation difficulty, and fears of opportunism (the disclosure dilemma) when selecting a partnership (Carter, 1989; Contractor and Ra, 2002; Li et al., 2008). Similarly, power derives from locking-up the most favourable sources of raw material, leading to competitive costswitching strategy (Porter, 1980; Dovere et al., 2016; Jitpaiboon et al., 2016). Access to key resources, prior knowledge characteristics and threat of opportunism are thus crucial variables to be considered for successful development of advanced services.

Related literature analyses firms' choice of collaborative partners, management of relationships within the network, establishment of competitive position and tracing of competitors (Harland, 1996). Analysing competitive strategies within these networks also requires considering transactional behaviour and entry barriers, product and technology characteristics, degree of concentration and network level (Chang et al., 2012). Transactional behaviour and entry barriers relate to collaborative strategic network partnerships (Bensaou, 1999). SC partnership is based entirely on business relationships that deliver benefits - resources and capabilities generated, and access to other resources and competencies (Walter et al., 2001). Improved partnership management requires determining the essential SC members and granting them special attention or resources (Lambert and Cooper, 2000).

In servitization contexts, understanding SCN dynamics is essential. The complexity of advanced service offerings necessitates extra organisational functions and many actors in the provider's external network (Lockett et al., 2011). For instance, customer participation introduces potential uncertainty, requiring firms to envision customer demands in order to manage the value chain effectively and efficiently (Grönroos, 2011; Vendrell-Herrero et al., 2017). Because SCN partners develop actionable strategies from customer information (Jüttner, 
et al., 2007), information is particularly important in the context of advanced services (Baines and Lightfoot, 2013).

\section{Risk perception in implementing advanced services}

Manufacturing firms generally perceive implementation and adoption of advanced services as a high-risk strategy (Benedettinini et al., 2015), perhaps due partly to traditional product-based mind-set, and the orientation of resources and capabilities, which have been primarily towards product design and innovation (Pezzotta et al., 2016). Recently, a few experts have addressed the other side of the issue, uncertainties and risks associated with servitization. Josephson et al. (2016) investigate how firms' contextual factors-strategic coherence (R\&D intensity, service relatedness) and resource allocation (marketing intensity, unabsorbed slack, absorbed slack) - affect the relationship between risk and service transition. $\mathrm{Ng}$ and Nudurupati (2010) examine risks such as complexity and unpredictability of costs when implementing outcome-based contracts in the defence industry. Sawhney et al. (2003) study market risks (customer's perspective), capability risks (provider's organisational perspective) and financial risks associated with servitization.

As with any new initiative, manufacturing firms that start to compete through services must internalise new risks (Keh and Pang, 2010). Nordin et al. (2011) argue that these risks include significant operational risks (e.g., capacity constraints, human resource and leadership issues), strategic risks (e.g., decline in competitiveness, reputational issues) and financial risks (e.g., direct negative impacts on profit, revenue and market share). Moreover, manufacturing firms providing such services may have to initiate partnerships with potential competitors to align incentives and processes, and optimise SC performance (Mathieu, 2001). Although all SCs must align incentives, alignment is riskier in the context of servitization, which involves companies collaborating with competitors. More positively, such collaboration can enable risksharing and mitigate costs when moving into service provision (Bustinza et al., 2017; Lafuente et al., 2017).

Understanding and empirical analysis of whether changes in SCN dynamics (e.g. initiating strategic partnership with other players) have any differential effect on risk perception is limited. Research associates good comprehension of relevant technologies with low risk perception (Teece, 2007). Analysing strategic transformation of UK manufacturing firms, an exploratory study by Martinez et al. (2010) demonstrates that these firms show increased interest in establishing partnerships with suppliers when they become product-service providers: “...provision of an integrated offering requires intensive exchange of information and know- 
how" (Martinez et al., 2010, p.460). In the context of SCM and product-service provision, therefore, perceived risk increases as further information is needed and unexpected negative events (involving malfunctions in internal/external processes) or disruptions occur (Klassen and Vereecke, 2012). To shed light on the understanding of SCN dynamics in the context of advanced service implementation, the next section is devoted to analyse the case of the UK road transport industry, considering the trade-offs between partnerships selection and risk perception.

\section{Research methodology}

\section{The road transport industry and its key players}

To address the objectives of this paper, an integrated industry-level analysis deemed to be necessary in order to obtain information covering all relevant players, from the highest upstream to the lowest downstream.

The decision was taken to focus on the road transport industry, one of the key OEM (Original Equipment Manufacturer) industries in the UK. According to the latest figures from Transport Statistics Great Britain (2014), 68\% of domestic freight goods are moved by road; this indicates that other economic activity (logistics, retailing etc.) significantly depends on the efficient and effective functioning of the UK road transport sector. This vital industry was chosen for three main reasons:

- Number of manufacturers with varied business-to-business relations with suppliers and operators, highly relevant to the servitization debate.

- Effect of increased global competition, generating several organisational and technological transformations; varied risk perception and value network dominance.

- Significant role in UK economy, ensuring cost-effective flow of goods on which other commercial sectors depend.

In the UK, road transport operators either manage their distribution channels (act as their own account operators) or manage distribution for other companies by providing 'third-party logistics' (3PL - the provider of outsourced logistics services) or acting as 'haulers' (around $60 \%$ of UK road transport operations).

Between 2013 and 2014 alone, 78,000 goods vehicles (trucks and trailers) were licensed in the UK to operate nationally and internationally (Traffic Commissioners Report, 2014). During that period, operators' profit margins increased to $3 \%$, from $1 \%$ the previous year. Moreover, the 100 largest 3PL businesses in the UK are significant employers, accounting for over 331,000 employees (MotorTransport, 2014). Substantial variation exists, however, in 
individual operator size and turnover, from family-run businesses with a couple dozen employees and average turnover of $£ 2-3$ million to multinational operators with over 100,000 employees and turnover reaching $£ 1$ billion.

The UK road transport sector currently faces a range of technological, legislative and operational challenges impacting operators' ability to maintain competitiveness and profitability (Schroeder et al., 2016). For any SC to be effective, its companies must exploit the latest technology solutions and industry best practices, which help firms operate efficiently and productively while meeting customers' precise needs (Li et al., 2005). In this context, technology enables product-service integration to create competitive compelling value propositions $(\mathrm{Ng}$ and Smith, 2012; Kowalkowski et al., 2013), while supporting a service-centred view by enabling integration of business processes through the value network (Gunasekaran and Ngai, 2004). In the transport sector specifically, it is plausible to assume that product-service providers can achieve economies of scope (Kastalli and Van Looy, 2013) by leveraging technological capabilities and spanning transaction costs (Williamson, 1991).

The UK road transport industry consists of a network of key players (see Figure 1) categorised into three main groups:

1. Producers, two sub-groups: i) suppliers providing products/services used by truck/trailer manufacturers and their customers (e.g., operators), ii) main truck/trailer manufacturers. The past decade has seen four major types of financial arrangements between these manufacturers and their clients - primarily transport operators.

2. Operators, two sub-groups: i) transport operators - main users of trucks/trailers, and ii) services supporting them. Usually operate $24 / 7$ and work closely with retailers from various industries. The relationship between a transport operator and other relevant industry players depends fundamentally on the operator's resources. Large operators normally own the product (trucks/trailers) and acquire maintenance and other complementary services from third-party service providers; small operators tend to rent fleets and associated services from intermediate operators (fleet management companies), the second sub-group of operators. Fleet management companies provide a wide range of services chiefly for transport operators and end-users, including fleet financing, fleet maintenance, telematics services (tracking, diagnostics), and driver and fuel management. Such services minimise operator and end-user risks associated with vehicle investment, improve efficiency and productivity, and reduce overall operating costs. 
Figure 1. The UK road transport industry: value chain used to analyse implementation of advanced services

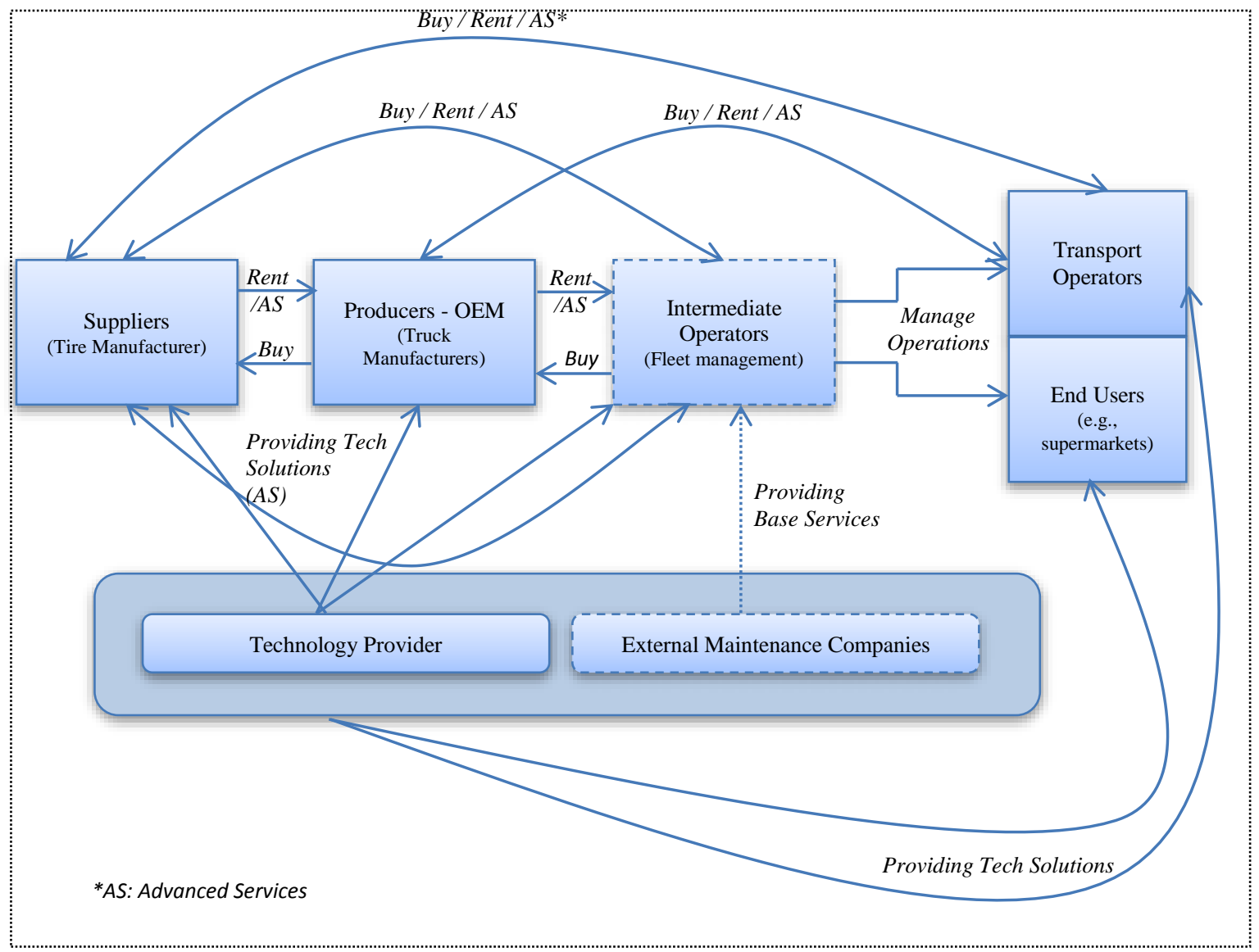

3. Technology providers. Provide technology platforms such as Telematics to every industry player, including tire manufacturers and suppliers, truck/trailer manufacturers, fleet management companies, operators and end-users. Telematics within the road transport involves sensors and connectivity devices that constantly generate and transmit data about the vehicle, which enable clients to know exactly fleets location, use, and economy and safety of driving. Journey management tools enable more effective planning. Technology providers normally offer both hardware and software, which explains why, in theory, they are considered as product-service providers.

\section{Data collection}

The UK's road transport industry encompasses a limited number of key players. Given the aim of this research, we designed a qualitative study approach based on collection of information from multiple firms and 'how and why' questions (Yin, 2013). 
Our cross-comparison of different firms explored the complex dynamics of the road transport industry's SCN and examined respondents' risk perceptions, as well as their potential interest in engaging in partnerships. To our knowledge, this is the first-ever study to analyse risk perception and partnering priorities in implementation of service business models in manufacturing environments.

Our case study methodology is appropriate because case study is particularly helpful when availability of empirical evidence or theoretical development is limited (Santos and Eisenhardt, 2005). In line with Angwin et al. (2016) and Gomes et al. (2012), we adopted a multiple-firm case study approach to enable replication logic through systematic analysis of various firms (Eisenhardt and Graebner, 2007), generating better-grounded, more comparable, more generalizable results than are possible using single-firm analysis. This method also helped avoid potential bias from misjudging representativeness of a single event (Tversky and Kahnema, 1986), a major limitation of using single observations to ground conclusions.

There were two key reasons for choosing the case studies: (1) we selected at least one firm from each position identified in Figure 1, a firm that represents a key player in the chosen industry; (2) selection of the case studies was partly dictated by opportunities to gain quality access to senior management of these firms. Data were collected through 14 in-depth, semistructured, face-to-face interviews with two Senior Executives - including Chief Executive Officer (CEO), Chief Innovation Officer (CIO), Chief Operating Officer (COO), Technical Director and Services Director - from seven companies in UK road transport.

All interviews were conducted January - November 2015. To reduce respondent bias in any individual organisation, two interviews were conducted per company. The interviews, about 2 hours each, were tape-recorded and transcribed immediately. As Table 1 shows, the sample included two producers: a tire supplier (Company A) and a truck manufacturer (Company B); a technology provider (Company C); three operators - small (Company E), medium-sized (Company F) and large (Company G); and a fleet management company (Company D). This methodology generated insightful details on company strategies and motivations based on SC position (Lambert and Cooper, 2000). ${ }^{1}$

\footnotetext{
${ }^{1}$ External maintenance companies, while part of the value network of the road transport industry, are not involved in implementing and adopting advanced services, as they only provide basic services (e.g., spare parts). We include them in Figure 1 for completeness but do not analyse them here.
} 
Table 1. Overview of participating companies

\begin{tabular}{|c|c|c|c|c|}
\hline \multirow{2}{*}{$\begin{array}{l}\text { Company } \\
\text { Supplier: } \\
\text { manufacturer }\end{array}$} & \multicolumn{4}{|c|}{ Turnover $(£)$ umber of Employerganisational Structurrviewees } \\
\hline & $\sim 10 \mathrm{bn}$ & $>70,000$ & Divisional & $\mathrm{CIO} / \mathrm{COO}$ \\
\hline $\begin{array}{l}\text { Producer (OEM): Truck/trailı } \\
\text { ufacturer }\end{array}$ & $\sim 550 \mathrm{~m}$ & $>800$ & Line and Staff & O/Services Direc \\
\hline Technology provider & $\sim 30 \mathrm{~m}$ & $>250$ & Line and Staff & $\mathrm{CEO} / \mathrm{COO}$ \\
\hline Fleet management & $\sim 60 \mathrm{~m}$ & $>90$ & Functional & O/Technical Direr \\
\hline $\begin{array}{l}\text { Transport operator: } \\
11\end{array}$ & $\sim 7 \mathrm{~m}$ & $>70$ & assic Family-run $\mathrm{Bu}$ & nèO/Services Direc \\
\hline $\begin{array}{l}\text { Transport operator: } \\
\text { ium-sized }\end{array}$ & $\sim 130 \mathrm{~m}$ & $>220$ & Functional & $\mathrm{CEO} / \mathrm{COO}$ \\
\hline $\begin{array}{l}\text { Transport operator: } \\
\text { e }\end{array}$ & $\sim 1.1 \mathrm{bn}$ & $>15,000$ & Functional & O/Services Direc \\
\hline
\end{tabular}

The nature of the advanced service analysed is important: providing real-time telematics and electronic proof-of-delivery solutions through in-truck hardware installation. In the study context, this service as performed by a technology provider that began as a knowledge-intensive business service (KIBS) company but now also manufactures hardware required to implement the service. At the time of the interviews, the technology provider and OEM were partners.

\section{Measuring risk perception and willingness to form partnerships}

Implementing new projects generally increases managers' perception of risk (Cantu et al., 2013). Services create value and capture processes different from those relating to products, adding specific risks to a firm's portfolio (Keh and Pang, 2010) Recent research indicates that servitized manufacturers are more likely to go bankrupt than non-servitized (Benedettinini et al., 2015), supporting the idea that service business models pose risks to the organisations adopting and implementing them. There are more servitized firms that declare bankruptcy that expected as strategic decision' frameworks do not take account of risk and pay attention to incentive design in servitizing business models (Neely, 2008). 
For the in-depth interviews, we designed a numerical exercise to measure interviewees' risk perception, based on four assumptions:

- Managerial decision-making ultimately depends on the trade-off between expected return and risk of implementing organisational change (Fama and MacBeth, 1973).

- $\quad$ Assuming that managers and shareholders are risk-averse, firms' increased risk-taking is linked directly to expectations of higher returns in dividends and compensation for managers (Coles et al., 2006).

- As service implementation is a binary decision, our analysis does not consider intensity of investment required to implement service offerings. This approach follows the model developed by Gimeno et al. (1997) to analyse preference for being an employee or selfemployed and extended by Vendrell-Herrero et al. (2014) to analyse preference for developing traditional or innovative projects.

- The intrinsic risk involved in a new project and in including a new partner are independent events (Van Dorp and Duffey, 1999).

The numerical exercise, conducted following each interview, drew on the 'payment card' method (Epstein and Widener, 2011). Using as baseline the profit the firm generated over the previous three years, we asked interviewees to ascribe a value to the increase in their firm's profitability expected from incorporating advanced services into their portfolio. The payment card indicates how much the expected return should increase to compensate for the increased risk. It requires examining the company's expected return both with and without the investment. If the company does not invest $(\mathrm{I})$, ceteris paribus, expected return $\left(\mathrm{R}_{\mathrm{NI}}\right)$ for the current period (t) will equal the company's profits in previous years $(\alpha)$ :

$$
\mathrm{R}_{\mathrm{NI}}=\alpha \quad \text { (Equation 1) }
$$

If the company does invest and integrate advanced services into its portfolio, expected return $\left(R_{I}\right)$ will equal past profits plus a positive unknown function of the risk taken, $f($ risk $)$ :

$$
\mathrm{R}_{\mathrm{I}}=\alpha+\mathrm{f}(\text { risk }) \quad \text { (Equation 2) }
$$

The difference between Equations 1 and 2 yields:

$$
\Delta \mathrm{I} \rightarrow \mathrm{R}_{\mathrm{I}}-\mathrm{R}_{\mathrm{NI}}=\mathrm{f}(\text { risk }) \quad(\text { Equation } 3)
$$

The payment card measures this function of risk. In our methodology, it offers the firm's managers development of a new servitization project ( $\underline{\text { no }}$ partners) at a varied set of expected returns relative to the company's past performance $(\alpha)$. All values are positive, progressing from a small increase in profitability $(5 \%)$ to a large one (100\%). These stepwise increments occur 
sequentially, with the interviewee switching from one expected return to the next. The point at which the interviewee stops switching determines risk perception concerning integration of advanced services into the portfolio.

The payment card also informs of expected return when a new servitization project is developed and a partner $\underline{i s}$ involved. Here, expected return $\left(\mathrm{R}_{\mathrm{IP}}\right)$ will be:

$$
\mathrm{R}_{\mathrm{IP}}=\alpha+\mathrm{f}(\text { risk })+\mathrm{g}(\text { partner }) \quad(\text { Equation } 4)
$$

In Equation 4, ' $\mathrm{g}(\mathrm{)})$ is a positive unknown function; 'partner' stands for percentage of project funded by partner. The difference between Equations 4 and 2 measures the impact of an increase in partnering $(\Delta \mathrm{P})$ once implementation of advanced services is decided:

$$
\left.\Delta \mathrm{P} \rightarrow \mathrm{R}_{\mathrm{IP}}-\mathrm{R}_{\mathrm{I}}=\mathrm{g}(\text { partner }) \text { (Equation } 5\right)
$$

Again, difference in expected return reveals the perceived benefit or loss involved in having a partner. Operationally, we offered interviewees three additional payments, each presenting the same servitization project but a percentage of partner involvement, from $25 \%$ to 75\%. These cards elicited interviewees' perception of having external partners in the investment, $\mathrm{g}$ (partner). We assumed managers would select the partnering level with lowest perceived risk. An upward-sloping relationship between expected risk and partnering is therefore associated with preference for purely in-house strategy (no partner), and a downward-sloping relationship with preference for an outsourcing strategy (partner provides $75 \%$ or more of the investment).

\section{Findings}

This section examines the evidence collected during the payment card exercise, subsequently complemented with insights from the interviews. Figure 2 summarises the results of the payment card exercise. In Panel A, switching points are averaged depending on the interviewees' position in the value network: four from the supplier and the OEM in our sample, two from the advanced service provider, and eight from the four operators interviewed.

To interpret Panel A correctly, we first examine the point at which partnering equals zero. The vertical axis indicates perceived risk, measured by average return required when developing an in-house advanced service. While, on average, interviewees from the technology provider (Company C) associated very low risk (5\%) with this strategy, Companies A and B perceived greater risk and requested a $13.75 \%$ increase in expected return. On average, operators (Companies D -G) demanded even larger compensatory returns (20\%). 
The second step examines how risk perception changes when a partner is available. For interviewees from manufacturing Companies A and B and technology provider Company $\mathrm{C}$, risk perception rises as partnering increases, resulting in request for larger expected return. This upward-sloping curve indicates that the supplier, OEM and product-service provider strongly prefer integration of advanced services in-house and no partner. As the Senior Engineering Director of Company B (the OEM) stated, “...we believe that through the technology that has been produced and implemented in-house, we'd be able to serve a bigger market share and therefore increase our revenue stream..." By contrast, operators show a downward-sloping relationship between extent of partnership and risk. In telematics technology, a senior executive from Company G (large operator) argued that "...the scale of our operations is very large, therefore we have to spend a lot on advanced services to gain the real benefit. Given the low margin factor of the market, there is no immediate willingness towards these changes in our company."

Table 2 summarises the results in Panel A. Qualitative evidence suggests three related factors: accumulated knowledge of relevant technologies required to implement advanced services, company size, and willingness to disclose information to potential competitors. For Company F's CEO (medium-sized operator), “...the technology for gathering relevant information, including drivers' behaviour, fuel consumption etc., in our view, is not quite advanced yet. Hence, we don't believe that the ROI is attractive for us to introduce these services in-house...” Similarly, Company E's CEO (small operator) argues, “...the founders of the company were engineers, so it was a massive decision for us to outsource the tire-related services. But we are a small operator and reached a point that we didn't have any other options...we thought and still think that we made the right decision because we have saved a lot on this and have improved our operations considerably..."

Table 2. Risk perception and partnering preference

\begin{tabular}{c|c|c|c}
\multicolumn{2}{c}{ Company } & $\begin{array}{c}\text { Perceived Risk } \\
\text { f(risk })\end{array}$ & Make-or-buy Decision \\
\hline \multirow{2}{*}{$\begin{array}{c}\text { Upstream } \\
\text { network }\end{array}$} & Technology provider & Low & In-house \\
\hline $\begin{array}{c}\text { Downstream } \\
\text { network }\end{array}$ & Operators & Medium-high & In-house \\
\hline
\end{tabular}

From Table 2, we can develop Panel B, where the vertical axis is column 2 (perceived risk from low to high) and the horizontal axis is column 3 (make-or-buy decision from in-house 
to total outsourcing of advanced services development). Our evidence suggests that companies downstream lack access to strategic knowledge, increasing risk perception among end clients (operators) while increasing the need to outsource to more knowledgeable companies upstream. Knowledge acquisition (in-house or through partnerships) can lock-out competitors and secure strategic network positioning in servitized industries. Remarkably, Companies B and C seem to prioritise this network positioning and lock-in consumers related to increasing risk associated with partnering (Panel B, Figure 2; Table 2), summarising the position of the main players in UK road transport.

Overall, evidence suggests that upstream value chain producers prefer to develop advanced services in-house, associating their implementation with medium risk. This perception increases greatly among downstream value chain operators, who associate higher risk with unexpected negative events from malfunctions/disruptions in internal processes (Klassen and Vereecke, 2012). In reality, outsourcing or partnering decisions moderates this higher risk.

\section{Discussion}

Our analysis shows that companies with more knowledge and information about the value of advanced services perceive lower risk and prefer in-house development, retaining control of labour skills and specific knowledge. Advanced service development is thus linked to the issues of information asymmetry and the difficulty of evaluating the benefits expected from firms that do not have the technological knowledge required (Contractor and Ra, 2002; Kleemann and Essig, 2013). This conclusion is aligned with Teece (2007), who argues that understanding the relevant technology reduces inherent risk associated with incremental and radical innovations, and Kowalkowski et al. (2013), who consider technology as a key enabler for implementing new product-services. While our evidence suggests that upstream companies prefer to develop technology in-house, pointing out the importance of protecting knowhow to secure competitive advantage ( $\mathrm{Li}$ et al., 2005), companies downstream prefer partnership, as they do not fear the information disclosure dilemma (Carter, 1989). Risk perception about technology implementation shows the higher risk perception downstream, the more distant point for understanding the relevant technology. 
Figure 2. Panel A: Empirical relationship between risk and partner

Panel $B$ : Mapping value configuration in UK road transport industry

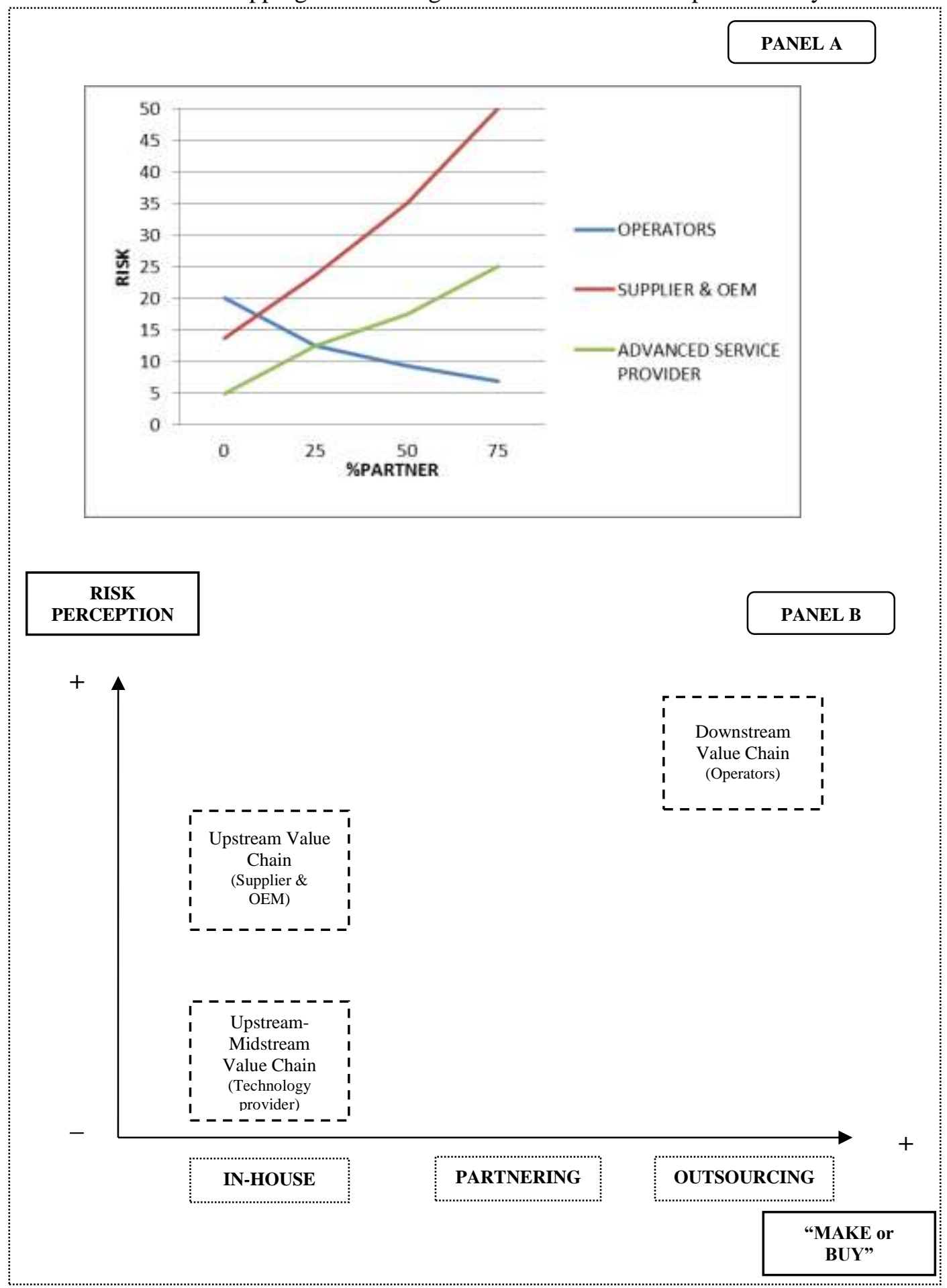

To better understanding our results, we follow the model for designing SC solutions developed by Collin et al. (2009) for products, by Holmström et al. (2010) for services, and 
developed further for product-services by Bustinza et al. (2013). Figure 3 portrays strategic positioning in the SCN in the context of UK road transport advanced services implementation. This model identifies offer-demand visibility points as well as consumer locking points. As the Figure shows, solutions designed by advanced service providers establish resource positioning through an OEM, enabling the technology provider to lock the value chain through strategic alliance with the OEM by installing the hardware (product) in trucks and delivering value propositions to all downstream operators, including intermediate operators, transport operators and end-users.

Since value chain visibility is a prerequisite to implementing advanced services, establishing a sub-regime of power in the value chain through upstream positioning decreases risk, creates entry barriers and transmits implementation costs to the entire value chain (Figure 3). This upstream strategy secures the status quo of the SCN, implying lock-out of potential downstream competition. This conclusion on the importance of strategic partnership when implementing advanced services reinforces Vandermerwe and Rada (1998), who claim that one reason for manufacturing firms to servitize is to lock-out competitors.

Most value chain networks have power regimes designed to secure a greater share of network profits (Gelderman et al., 2008) and avoid fragmentation (Watson, 2001). Like previous industrial case studies, ours suggests that strategic network positioning belongs to the industry player with greatest knowledge of new technology. In the road transport industry, network positioning derives from good understanding of hardware and software technologies enabling cost-efficient truck operations. Our evidence indicates that firms need to visualise the SC network before selecting an industry business ecosystem point of entry for advanced services. Further, collaborative strategic partnership within the network (Bensaou, 1999) is a key strategy in building upstream entry barriers for better value chain positioning (Chang et al., 2012). Such partnerships can be secured by connecting with a technology enabler, since such organisations have the strategic knowledge to develop significant value propositions. 
Figure 3. Manufacturing firm that maintains traditional product provision and locks supply chain network through technology provision

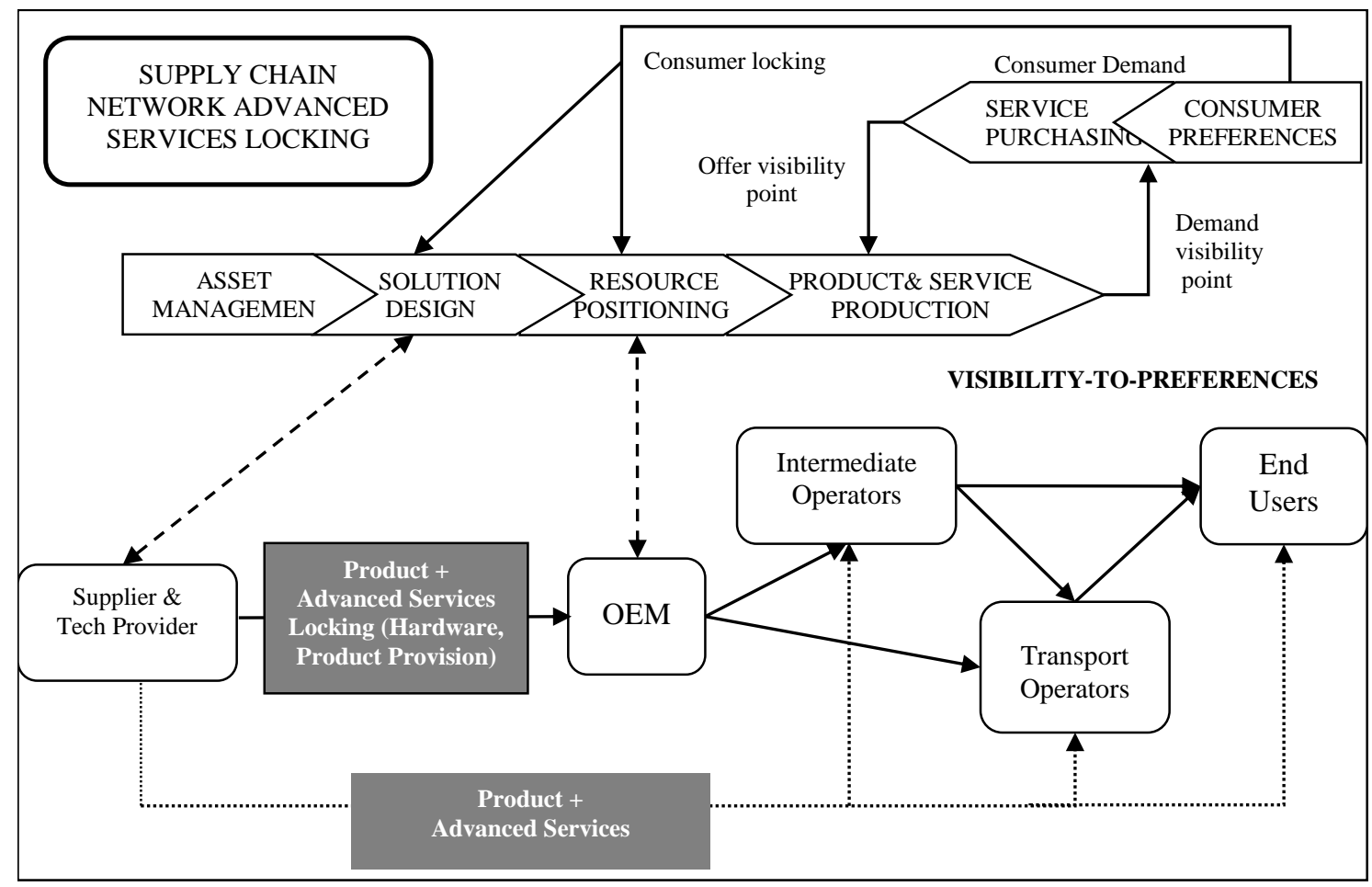

\section{Conclusions}

Our key aim was to examine assumptions requiring further analysis in manufacturing firms implementing service strategies (Valtakoski, 2016) - for example, firms' need to establish strategic partnerships in addition to managing supply and demand (Harland, 1996). Our research undertakes a payment card exercise to estimate risk perception among companies operating in different positions within the UK road transport industry's SC. This is a novel approach to understand firm operations and perceptions. Though the payment card has some underlying limitations, e.g. the assumption that investment is a binary variable, its main advantage is that it provides a novel procedure to determine best point of entry in the SCN by analysing risk perception and partnering propensity in the context of implementing advanced services. Consequently, the method is useful for building sustainable competitive edge for products and services.

The results also show the extent to which partnerships can provide strategic information for better understanding of product-service value propositions (Uluaga and Reinartz, 2011; Wu and Choi, 2005). Such strategic partnerships must consider point of entry by analysing the entire SCN. This analysis is crucial to advanced services implementation in identifying the best partners to link processes (Lambert and Cooper, 2000). Our evidence follows the line of recent 
findings demonstrating that firms select partners and governance structure as mechanisms to safeguard valuable technological knowledge in product innovation alliances (Li et al., 2008). An important contribution of this study is thus its identification of some specific mechanisms relevant in the context of service innovation. Our findings suggest that decisions on how to implement advanced services depend on accumulated knowledge, firm resources and the disclosure dilemma (Carter, 1989), factors ultimately influencing managerial risk perception.

Analysing the value chain not only reveals the best option for partnership. It also contributes to creating specific models to design SC solutions by considering customer demand chain visibility (Collin et al., 2009), current product-service portfolios (Bustinza et al., 2013), and technology enablers and key SC members connected to a firm's processes (Lambert and Cooper, 2000). Firms should consider how their network position affects their value propositions and structural power derived from their network position ( $\mathrm{Wu}$ and Choi, 2005).

A firm's network position is closely related to a range of assumptions about servitization (Baines, et al, 2017). Previous studies demonstrate downstream network positioning for lock-in customers in the context of servitization (Vandermerwe and Rada, 1989; Bustinza et al., 2013; Vendrell-Herrero et al., 2017). This paper breaks new ground by proposing competitive strategies oriented to upstream positioning for traditional manufacturing firms introducing advanced services. A locking strategy established through trading partners can build entry barriers against downstream competitors (Chang et al., 2012). Such upstream-focused strategies reinforce the literature on SCM practices, particularly in the context of strategic supplier partnerships, customer relationships and information-sharing (Li et al., 2005). Building on the idea that structural power derived from a firm's network position secures integration and a greater share of network profits (Bastl et al., 2013; Gelderman et al., 2008), this paper's counterexample (UK road transport industry) deepens insight into the importance of network positioning in servitization.

Another contribution involves the relevance of possessing strategic knowledge when locking-out competitors through services. In our case study, a new company possessed such knowledge. Recent research concludes that one in ten manufacturers worldwide outsource service activity to service companies (KIBS) to reduce risks (Bustinza et al., 2015). Modern industry dynamics go beyond Schumpeter's idea of small new entrants competing with large incumbents. Large technology-based companies (e.g., Apple, Google) threaten to enter the automotive industry (Schulze et al., 2015). Risk perception among such large technology-based firms may differ entirely from that of KIBS businesses, opening scope for further research on how both industry dynamics in innovative changing industrial environments (Suarez et al., 2015) 
and characteristics of new entrants' influence partnerships and network dominance in increasingly servitized manufacturing contexts.

What, then, are this study's most significant implications for managers in manufacturing?

- Importance of selecting the right partner, especially considering the high percentage of failed partnerships. Good understanding of technology as enabler of product-service ( $\mathrm{Ng}$ and Smith, 2012) and business process integration (Gunasekaran and Ngai, 2004) is central. Strategic technology supplier partnerships can provide economies of scope that span transaction costs (Williamson, 1991).

- Importance of firms ensuring visibility of the entire value chain before taking any strategic decision. This helps to reveal the sub-regimes of suppliers, and how traditional competitive strategies apply to particular service contexts (Finne and Hölmstrom, 2013). Our results help managers to better articulate decision-making procedures in product-service implementation.

While we acknowledge possible interviewee bias, the results improve practitioners' comprehension of manufacturing industry dynamics worldwide. Study limitations arise from various methodological assumptions and small sample within one industry. Future research should relax some assumptions (players may be risk-lovers or risk-neutral; service strategy is a continuum, not a dichotomy), and include more players. This opens an intriguing research avenue for analysing value constellations (Brax and Visintin, 2017) as a framework for understanding partnership in complex networks. Further inquiry could extend findings by analysing risk perceptions of multinational companies in different countries. Future research should seek methods to identify appropriate business models in such contexts to demonstrate the models' importance as value-generating mechanisms for both customers and the organisations that aim to meet those customers' needs.

\section{Acknowledgements}

This work was supported by EPSRC Grants Ref EP/K014064/1, EP/K014072/1, EP/K014080/1 'Transforming the adoption of Product -Service Systems through innovations in applied gaming technology'; a joint project with Aston Business School, and the Advanced Manufacturing Research Centre, University of Sheffield. In addition we received support from the European Commission under the Horizon 2020 project MAKERS: Smart Manufacturing for EU Growth and Prosperity (691192), the Spanish Government under Grant ECO2014-58472-R, and the Junta de Andalusia under Grant P11-SEJ-7294. 


\section{References}

Angwin, D.N., Mellahi, K., Gomes, E., and Peter, E. (2016). How communication approaches impact mergers and acquisitions outcomes. The International Journal of Human Resource Management, 27(20), 2370-2397.

Ardolino, M., Rapaccini, M., Saccani, N., Gaiardelli, P., Crespi, G., and Ruggeri, C. (2017). The role of digital technologies for the service transformation of industrial companies. International Journal of Production Research, In Press.

Baines, T.S., and Lightfoot, H. (2013). Made to serve: How manufacturers can compete through servitization and product service systems. New York: John Wiley and Sons.

Baines, T.S., Ziaee Bigdeli, A., Bustinza O.F., Guang-Shi, V., Baldwin, J., and Ridgway, K. (2017). Servitization: Revisiting the State-of-the-art and Research Priorities. International Journal of Operations \& Production Management. DOI: 10.1108/IJOPM-06-2015-0312 (In Press)

Bastl, M., Johnson, M., and Choi, T.Y. (2013). Who's seeking whom? Coalition behavior of a weaker player in buyer-supplier relationships. Journal of Supply Chain Management, 49(1), 8-28.

Benedettinini, O., Swink, M., Neely, A., Brown, S. and Brown, S. (2015). Why do servitized firms fail? A risk-based explanation. International Journal of Operations and Production Management, 35(6), 946979.

Bensaou, M. (1999). Portfolios of buyer-supplier relationships. Sloan Management Review, 40(4), 35-44.

Bikfalvi, A., Lay, G., Maloca, S., and Waser, B.R. (2013). Servitization and networking: Large-scale survey findings on product-related services. Service Business, 7(1), 61-82.

Brax, S. A., and Visintin, F. (2017). Meta-model of servitization: The integrative profiling approach. Industrial Marketing Management, 60, 17-32.

Bustinza, O.F., Parry, G., and Vendrell-Herrero, F. (2013). Supply and demand chain management: The effect of adding services to product offerings. Supply Chain Management: An International Journal, $18(6), 618-629$.

Bustinza, O.F., Ziaee Bigdeli, A., Baines, T., and Elliot, C. (2015). Servitization and competitive advantage: The importance of organizational structure and value chain position. Research-Technology Management. 58(5), 53-60.

Bustinza, O.F., Gomes, E., Vendrell-Herrero, F., and Baines, T. (2017). Product-service innovation and performance: The role of collaborative partnerships and $\mathrm{R} \& \mathrm{D}$ intensity. $R \& D$ Management, In Press.

Cantu, C., Corsaro, D., Fiocca, R., and Tunisini, A. (2013). IMP studies: A bridge between tradition and innovation. Industrial Marketing Management, 42(7), 1007-1016.

Carter, A.P. (1989). Knowhow trading as economic exchange. Research Policy, 18(3), 155-163.

Chang, C.W., Chiang, D.M., and Pai, F.Y. (2012). Cooperative strategy in supply chain networks. Industrial Marketing Management, 41(7), 1114-1124.

Coles, J.L., Daniel, N.D., and Naveen, L. (2006). Managerial incentives and risk-taking. Journal of Financial Economics, 79(2), 431-468.

Collin, J., Eloranta, E., and Holmström, J. (2009). How to design the right supply chains for your customers. Supply Chain Management: An International Journal, 14(6), 411-417.

Contractor, F.J., and Ra, W. (2002). How knowledge attributes influence alliance governance choices: A theory development note. Journal of International Management, 8(1), 11-27.

Cooper, M.C., Lambert, D.M., and Pagh, J.D. (1997). Supply chain management: More than a new name for logistics. The International Journal of Logistics Management, 8(1), 1-14.

Crozet, M., and Milet, E. (2017). Should everybody be in services? The effect of servitization on manufacturing firm performance. Journal of Economics \& Management Strategy, In Press. 
Dovere, E., Cavalieri, S., and Ierace, S. (2016). RFId systems for moveable asset management: An assessment model. International Journal of Production Research, In Press.

Durugbo, C. (2014). Strategic framework for industrial product-service co-design: Findings from the microsystems industry. International Journal of Production Research, 52(10), 2881-2900.

Eisenhardt, K.M., and Graebner, M.E. (2007). Theory building from cases: Opportunities and challenges. Academy of Management Journal, 50(1), 25-32.

Ellram, L.M., and Cooper, M.C. (1990). Supply chain management, partnership, and the shipper-third party relationship. International Journal of Logistics Management, 1(2), 1-10.

Epstein, M.J., and Widener, S.K. (2011). Facilitating sustainable development decisions: Measuring stakeholder reactions. Business Strategy and the Environment, 20(2), 107-123.

Fama, E.F., and MacBeth, J.D. (1973). Risk, return and equilibrium: Empirical tests. Journal of Political Economy. 81(3), 607-636.

Finne, M., and Holmström, J. (2013). A manufacturer moving upstream: Triadic collaboration for service delivery. Supply Chain Management: An International Journal, 18(1), 21-33.

Finne, M., Turunen, T., and Eloranta, V. (2015). Striving for network power: The perspective of solution integrators and suppliers. Journal of Purchasing and Supply Management, 21(1), 9-24.

Gebauer, H., Paiola, M., and Saccani, N. (2013). Characterizing service networks for moving from products to solutions. Industrial Marketing Management, 42(1), 31-46.

Gelderman, C.J., Semeijn, J., and De Zoete, R. (2008). The use of coercive influence strategies by dominant suppliers. Journal of Purchasing and Supply Management, 14(4), 220-229.

Gimeno, J., Folta, T.B., Cooper, A.C., and Woo, C.Y. (1997). Survival of the fittest? Entrepreneurial human capital and the persistence of underperforming firms. Administrative Science Quarterly, 42(4), $750-778$.

Gomes, E., Angwin, D., Peter, E., and Mellahi, K. (2012). HRM issues and outcomes in African mergers and acquisitions: A study of the Nigerian banking sector. The International Journal of Human Resource Management, 23(14), 2874-2900.

Grönroos, C. (2011). A service perspective on business relationships: The value creation, interaction and marketing interface. Industrial Marketing Management, 40(2), 240-247.

Gunasekaran, A., and Ngai, E.W. (2004). Information systems in supply chain integration and management. European Journal of Operational Research, 159(2), 269-295.

Harland, C.M. (1996). Supply chain management: Relationships, chains and networks. British Journal of Management, 7(s1), 63-80.

Huikkola, T., Kohtamäki, M., and Rabetino, R. (2016). Resource realignment in servitization: A study of successful service providers explores how manufacturers modify their resource bases in transitioning to service-oriented offerings. Research-Technology Management, 59(4), 30-39.

Jitpaiboon, T., Gu, Q., ajd Truong, D. (2016). Evolution of competitive priorities towards performance improvement: a meta-analysis. International Journal of Production Research, In Press.

Josephson, B.W., Johnson, J.L., Mariadoss, B.J., and Cullen, J., 2016. Service Transition Strategies in Manufacturing Implications for Firm Risk. Journal of Service Research, In Press.

Jüttner, U., Christopher, M., and Baker, S. (2007). Demand chain management: Integrating marketing and supply chain management. Industrial Marketing Management, 36(3), 377-392.

Keh, H.T., and Pang, J. (2010). Customer reactions to service separation. Journal of Marketing , 74(2), $55-71$.

Klassen, R.D., and Vereecke, A. (2012). Social issues in supply chains: Capabilities link responsibility, risk (opportunity), and performance. International Journal of Production Economics, 140(1), 103-115. 
Kleemann, F. C., and Essig, M. (2013). A providers' perspective on supplier relationships in performance-based contracting. Journal of Purchasing and Supply Management, 19(3), 185-198.

Kowalkowski, C., Kindström, D., and Gebauer, H. (2013). ICT as a catalyst for service business orientation. Journal of Business and Industrial Marketing, 28(6), 506-513.

Kowalkowski, C., Gebauer, H., Kamp, B., and Parry, G. (2017). Servitization and deservitization: Overview, concepts, and definitions. Industrial Marketing Management, 60, 4-10.

Lafuente, E., Vaillant, Y., and Vendrell-Herrero, F. (2017). Territorial Servitization: Exploring the virtuous circle connecting knowledge-intensive services and new manufacturing businesses. International Journal of Production Economics, In Press.

Lambert, D.M., Emmelhainz, M.A., and Gardner, J.T. (1996). Developing and implementing supply chain partnerships. The International Journal of Logistics Management, 7(2), 1-18.

Lambert, D.M., and Cooper, M.C. (2000). Issues in supply chain management. Industrial Marketing Management, 29(1), 65-83.

Li, D., Eden, L., Hitt, M.A., and Ireland, R.D. (2008). Friends, acquaintances, or strangers? Partner selection in R\&D alliances. Academy of Management Journal, 51(2), 315-334.

Li, S., Rao, S.S., Ragu-Nathan, T.S., and Ragu-Nathan, B. (2005). Development and validation of a measurement instrument for studying supply chain management practices. Journal of Operations Management, 23(6), 618-641.

Lockett, H., Johnson, M., Evans, S., and Bastl, M. (2011). Product Service Systems and supply network relationships: an exploratory case study. Journal of Manufacturing Technology Management, 22(3), 293-313.

Mahut, F., Daaboul, J., Bricogne, M., and Eynard, B. (2017). Product-Service Systems for servitization of the automotive industry: a literature review. International Journal of Production Research, 55(7), 2102-2120.

Martinez, V., Bastl, M., Kingston, J., and Evans, S. (2010). Challenges in transforming manufacturing organisations into product-service providers. Journal of Manufacturing Technology Management, $21(4), 449-469$.

Mathieu, V. (2001). Product services: from a service supporting the product to a service supporting the client. Journal of Business and Industrial Marketing, 16(1), 39-61.

Meehan, J., and Wright, G. H. (2012). The origins of power in buyer-seller relationships. Industrial Marketing Management, 41(4), 669-679.

Motortransport (2014). Overview of the UK Commercial Vehicle Industry: 2014 Edition. London, UK.

Ng, I.C., and Nudurupati, S.S. (2010). Outcome-based service contracts in the defence industrymitigating the challenges. Journal of Service Management, 21(5), 656-674.

Ng, I.C., and Smith, L.A. (2012). An integrative framework of value. Review of Marketing Research, 9(special issue), 207-243.

Nordin, F., Kindström, D., Kowalkowski, C., and Rehme, J. (2011). The risks of providing services: differential risk effects of the service-development strategies of customization, bundling, and range. Journal of Service Management, 22(3), 390-408.

Pezzotta, G., Pirola, F., Rondini, A., Pinto, R., and Ouertani, M. Z. (2016). Towards a methodology to engineer industrial product-service system-Evidence from power and automation industry. CIRP Journal of Manufacturing Science and Technology, In Press.

Porter, M.E., and Heppelmann, J.E. (2014). How smart, connected products are transforming competition. Harvard Business Review, 92(11), 11-64.

Rabetino, R., Kohtamäki, M., and Gebauer, H. (2017). Strategy map of servitization. International Journal of Production Economics, In Press. 
Raddats, C., Burton, J., and Ashman, R. (2015). Resource configurations for services success in manufacturing companies. Journal of Service Management, 26(1), 97-116.

Ritter, T., and Gemünden, H.G. (2003). Interorganizational relationships and networks: An overview. Journal of Business Research, 56(9), 691-697.

Santos, F.M., and Eisenhardt, K.M. (2005). Organizational boundaries and theories of organization. Organization Science, 16(5), 491-508.

Sawhney, M., Balasubramanian, S., and Krishnan, V.V. (2003). Creating growth with services. MIT Sloan Management Review, 45(2), 34-44.

Schroeder, A., Galera Zarco, C., Baines, T., and Ziaee Bigdeli, (2016). Barriers to capturing the value of advanced services and digitisation in the road transport industry. In Spring Servitization Conference, Birmingham, United Kingdom.

Schulze, A., MacDuffie, J.P., and Täube, F.A. (2015). Introduction: Knowledge generation and innovation diffusion in the global automotive industry - change and stability during turbulent times. Industrial and Corporate Change, 24(3), 603-611.

Skjøtt-Larsen, T., Mikkola, J.H., and Kotzab, H. (2007). Managing the global supply chain. Copenhagen: Copenhagen Business School Press.

Suarez, F.F., Grodal, S., and Gotsopoulos, A. (2015). Perfect timing? Dominant category, dominant design, and the window of opportunity for firm entry. Strategic Management Journal, 36(3), 437-448.

Teece, D.J. (2007). Explicating dynamic capabilities: The nature and microfoundations of (sustainable) enterprise performance. Strategic Management Journal, 28(13), 1319-1350.

Traffic Commissioners Report (2014). UK: Traffic Commissioners for Great Britain

Transport Statistics Great Britain 2014, Department for Transport, UK Government

Tversky, A., and Kahneman, D. (1986). Rational choice and the framing of decisions. The Journal of Business, 59(4), 251-278.

Ulaga, W., and Reinartz, W.J. (2011). Hybrid offerings: How manufacturing firms combine goods and services successfully. Journal of Marketing, 75(6), 5-23.

Valtakoski, A. (2016). Explaining servitization failure and deservitization: A knowledge-based perspective. Industrial Marketing Management, In Press.

Vandermerwe, S., and Rada, J. (1989). Servitization of business: Adding value by adding services. European Management Journal, 6(4), 314-324.

Van Dorp, J.R., and Duffey, M.R. (1999). Statistical dependence in risk analysis for project networks using Monte Carlo methods. International Journal of Production Economics, 58(1), 17-29.

Vendrell-Herrero, F., González-Pernía, J. L., and Peña-Legazkue, I. (2014). Do incentives matter to promote high technology-driven entrepreneurial activity?. International Entrepreneurship and Management Journal, 10(1), 43-66.

Vendrell-Herrero, F., Bustinza, O.F., Parry, G., and Georgantzis, N. (2017). Servitization, digitization and supply chain interdependency. Industrial Marketing Management, 60, 69-81.

Visnjic, I., Jovanovic, M., Neely, A., and Engwall, M. (2017). What brings the value to outcome-based contract providers? Value drivers in outcome business models. International Journal of Production Economics, In Press.

Walter, A., Ritter, T., and Gemünden, H.G. (2001). Value creation in buyer-seller relationships: Theoretical considerations and empirical results from a supplier's perspective. Industrial Marketing Management, 30(4), 365-377.

Watson, G. (2001). Subregimes of power and integrated supply chain management. Journal of Supply Chain Management, 37(1), 36-41. 
Williamson, O.E. (1991). Comparative economic organization: The analysis of discrete structural alternatives. Administrative Science Quarterly, 36(2), 269-296.

Wise, R., and Baumgartner, P. (1999). Go downstream: The new profit imperative in manufacturing. Harvard Business Review, 77(5), 133-141.

Wu, Z., and Choi, T.Y. (2005). Supplier-supplier relationships in the buyer-supplier triad: Building theories from eight case studies. Journal of Operations Management, 24(1), 27-52.

Xie, W., Jiang, Z., Zhao, Y., and Shao, X. (2014). Contract design for cooperative product service system with information asymmetry. International Journal of Production Research, 52(6), 1658-1680.

Yin, R.K. (2013). Case study research: Design and methods. Sage publications.

Zhang, M., Guo, H., and Zhao, X. (2016). Effects of social capital on operational performance: Impacts of servitisation. International Journal of Production Research, In Press. 